\title{
Effect of Motor Imagery Training on Urinary Incontinence in Patients with Incomplete Spinal Cord Injury
}

\author{
MONA A. MOAWED, M.Sc.*; NAHED A. SALEM, Ph.D.*; YOUSSEF M. ELBALAWY, Ph.D.* and \\ AHMED A. AL-FIKI, Ph.D.** \\ The Departments of Physical Therapy for Neuromuscular Disorders and its Surgery, Faculty of Physical Therapy* and \\ Neurosurgery, Faculty of Medicine**, Cairo University, Egypt
}

\begin{abstract}
Background: Arising concern about motor imagery training and its effect on the incidence of urinary incontinence in incomplete spinal cord injury patients.

Aim of Study: This study was conducted to determine the effect of motor imagery training of pelvic floor muscles contraction on urinary incontinence in patients with incomplete spinal cord injury.

Material and Methods: Thirty patients with urinary incontinence due to over active bladder after incomplete spinal cord injury were selected randomly from the Outpatient Clinic of Kasr El-Aini, Teaching Hospital, Cairo University, and out-patient clinic, Faculty of Physical Therapy, Cairo University. From February 2019 to July 2019. Their age ranged from 18-40 years, with incomplete SCI above the level L1. All subjects were submitted to complete clinical evaluation and assessed using International Consultation on Incontinence Questionnaire Short Form (ICIQ-SF) and TG Myofeedback $420 \mathrm{~V}$. Only the study group underwent Vividness of Visua Imagery Questionnaire (VVIQ).

Results: By comparison between both groups, the study group (A) show increase in pelvic floor muscles strength and reduction in (ICIQ-SF) score more than group (B).

Conclusion: Motor imagery training of pelvic floor muscles can be effectively used to improve over active bladder incontinence and quality of life in patients with incomplete spinal cord injury.
\end{abstract}

Key Words: Motor imagery training - Urinary incontinence - Incomplete spinal cord injury.

\section{Introduction}

ACCORDING to the WHO (World Health Organisation), up to half a million people around the world suffer a spinal cord injury each year. Most often caused by road traffic crashes, accidents or violence, the loss of motor control or paralysis

Correspondence to: Dr. Mona A. Moawed, The Department of Physical Therapy for Neuromuscular Disorders and its Surgery, Faculty of Physical Therapy, Cairo University, Egypt significantly impacts quality of life and requires years of treatment and care [1].

With SCI patients, other organs and anatomic structures may also have been injured, and varies complications, such as cardiopulmonary, urinary bladder, intestine, and sexual function disorders and problems associated with inactivity, may be involved in the condition [2].

Neurogenic Overactive Bladder $(\mathrm{OAB})$, is characterized by urgency, with or without urgency urinary incontinence, usually with increased daytime frequency and nocturia in the setting of a clinically relevant neurologic disorder with at least partially preserved sensation [3] .

Conservative treatments for $\mathrm{OAB}$ include: Fluid management, bladder training, bladder control strategies, and pelvic floor muscle training. Firstline treatment with behavioral therapy presents essentially no risks to patients and should be offered to all patients [4]

Motor Imagery (MI) entails the cognitive task of imagining the performance of a given movement or specific task without physically executing it [5]

When undergoing imagery training, the same region of the brain that is activated when actual movements are made is greatly activated and muscle strength and speed are improved [6].

Normalization of brain motor system function might be useful as an adjunct to therapies aiming to restore movement after SCI, and motor imagery training might be one means to achieve this. This form of training involves internal reactivation of the representation of a specific motor action without 
any overt motor output, and is governed by the principles of central motor control [7].

\section{Aim:}

The aim of the study was to determine the effect of motor imagery training of pelvic floor muscles contraction on urinary incontinence in patients with incomplete spinal cord injury.

\section{Patients and Methods}

Patients were selected from Outpatient Clinic of Kasr El-Aini, Teaching Hospital, Cairo University, and out-patient clinic, Faculty of Physical Therapy, Cairo University. From February 2019 to July 2019, after agreeing to participate in the study. Patients enrolled in the study met the following criteria: (1) Their age ranged from 18 to 40 years old; (2) With incomplete SCI above the level L1 (3) Duration of illness the patient should pass the shock; (4) Have urinary incontinence caused by neurogenic detrusor over activity (5) Have stable medical condition. Exclusion criteria include previous stroke or other neurologic diseases or disorders, visual and hearing problems, incontinence due to other cause rather than detrusor over activity. And receiving Botox injections prior to or at any point during the study.

All subjects were submitted to complete clinical evaluation and assessed using International Consultation on Incontinence Questionnaire Short Form (ICIQ-SF) and TG Myofeedback 420V. Only the study group underwent Vividness of Visual Imagery Questionnaire (VVIQ).

\section{A- Assessment procedure:}

\section{1- Mental imagery ability assessment:}

The Vividness of Visual Imagery Questionnaire consists of four scenes (relative/friend, rising sun, a shop, a landscape). Each scene is divided into four specific aspects which have to be visualized (e.g., the color and shape of the trees). Participants rated all items on image vividness using a 5-point scale ('perfectly clear and vivid as normal vision when I really look at something' to 'no image at all, I only "know" that I am "thinking" about something'). Total scores range from 16 to 80 with higher scores indicating weaker imagery ability.

\begin{tabular}{lcccc}
\hline & Minimum & Maximum & Mean & $\begin{array}{c}\text { Std. } \\
\text { deviation }\end{array}$ \\
\hline Vividness of & 17.00 & 36.00 & 26.46 & 4.91 \\
Visual Imagery & & & & \\
Questionnaire & & & \\
(VVIQ) & & & \\
\hline
\end{tabular}

\section{2- Assessment of symptoms and impact of urinary incontinence (UI) on quality of life:}

The ICIQ-UI SF comprises three-scored items to assess the frequency of urinary incontinence (score $0^{\wedge} 5$ ), the amount of urinary incontinence (score $0^{\wedge} 6$ ), and its impact on the individual's quality of life (score $0^{\wedge} 10$ ). There is an un scored self-diagnostic item to assess the perceived causes of leakage. The score is obtained by adding the scores from the three-scored items together, to give a score range between zero and 21; the higher the score the greater the severity.

\section{3- Pelvic floor muscles strength assessment:}

The patient was asked to perform pelvic muscle exercise to be able to contract and relax this muscle as the following "contract as if you control your bowel action and uretheral orifice action concentrate in this action hold then relax for about three times".

Then the TG Myo feedback 420v rectal electrode was cleaned, covered with condom, lubricated by KY gel, and introduced gently inside the anus to evaluate anal closure pressure, and to measure the deeper internal pelvic floor muscle strength. The internal probe promoted proprioception, and aided in muscle awareness for every patient.

TG Myo feedback display was explained to the patient The therapist said, " a relaxed muscle will light up fewer bars, and the contracting muscle will light up many bars". Try to relax the muscle as much as possible. The number of bars seen at the top of the screen indicated the activity of the muscle. Patients were asked to contract the pelvic floor muscle as hard as they can around the electrode and count for 10 counts then relax, the step repeated 3 times. Then the mean of the three reading data calculated and recorded in the data sheet. This procedure is done pre and post the treatment. The data of the TG Myo feedback recorded in the computer memory. This data reflected the strength of pelvic floor muscles.

\section{Treatment procedure:}

1- Treatment were conducted at the outpatient clinic of Faculty of Physical Therapy, Cairo University.

2- Treatment were conducted 3 times/week, for 4 weeks.

- Control group: Received conventional physical therapy program, it includes:

Pelvic Floor Muscle Training (PFMT) and interferential therapy, the PFMT programme was explained verbally. 


\section{The pelvic floor muscle training:}

The programme consisted of up to 40 PFM contractions divided into 4 sets ( 3 sets of prolonged contractions and 1 set of short contractions). Subjects were asked to follow the programme three times daily in different positions; lying down, sitting and standing if possible subjects were also encouraged to perform PFM contractions at other times as soon as they felt a bladder urge. Subjects were asked to fill in a PFMT diary.

\section{Interferential therapy:}

- Patient position: The treatment was given in supine position with knees placed apart.

- Position of electrodes: Four electrodes covered with lint cloth pouch was used, two placed in lower abdomen (below the level of Anterior Superior Iliac Spine (ASIS) on both the sides) and the other two is placed on the medial aspects of both the thighs. Procedure: The treatment was given 3 sessions per week for 4 weeks. During each session of treatment the lint cloth pouch was changed regularly for each patient.

- Frequency: 0-10Hz.

-Intensity: Intensity based on subject's tolerance level.

-Duration: 15 minutes.

- Experimental group: Received Motor Imagery Training (MIT) of pelvic floor muscles followed by Pelvic Floor Muscles Training (PFMT) programme and interferential therapy.

Before the imagery training, a video of normal pelvic floor contraction was provided to the patient in a quiet treatment room for 10 minutes using visual and auditory information a good explanation of what the patient will imagine was explained to him.

Thereafter, the patient was instructed to close his/her eyes, while in a comfortable sitting position in a chair, and imagine the movement of pelvic floor muscles for 10 minutes with his/her body relaxed.

The motor imagery training group undergone imagery training for 10 minutes followed by (PFMT) and interferential therapy:

This study was approved by the Scientific Committee of the Faculty of Physical Therapy, Cairo University, Egypt. A written consent was obtained from each patient after they were provided with a thorough description of the study.

\section{Results}

Results revealed that by comparison between both groups, there is significant difference between both groups, the study group (A) show increase in pelvic floor muscles strength and reduction in (ICIQ-SF) score significantly more than group (B).

The results of the study were collected and assigned in regard of:

1- Physical characteristics of the subjects in both groups (A \& B).

Table (1): Mean values and standard deviation of physical characteristics of all participants in both groups (A \& B).

\begin{tabular}{|c|c|c|c|c|c|}
\hline \multirow{2}{*}{ Items } & \multirow{2}{*}{$\begin{array}{c}\text { Group A } \\
\text { Mean } \pm \text { SD }\end{array}$} & \multirow{2}{*}{$\begin{array}{c}\text { Group B } \\
\text { Mean } \pm \text { SD }\end{array}$} & \multicolumn{2}{|c|}{ Comparison } & \multirow{2}{*}{$\mathrm{S}$} \\
\hline & & & $t$-value & $b$-value & \\
\hline Age (years) & $31 \pm 6.63$ & $32.13 \pm 6.94$ & -0.457 & 0.651 & NS \\
\hline Body mass (Kg) & $67 \pm 9.94$ & $70.33 \pm 10.55$ & -0.872 & 0.39 & NS \\
\hline Height $(\mathrm{cm})_{2}$ & $168.73 \pm 11.07$ & $168.73 \pm 10.1$ & 0.00 & 1.00 & NS \\
\hline BMI $\left(\mathrm{kg} / \mathrm{m}^{2}\right)$ & $23.49 \pm 2.53$ & $24.59 \pm 2.02$ & -1.307 & 0.202 & NS \\
\hline
\end{tabular}

\section{2- ICIQ-SF:}

A- Within group comparison.

B- Between group comparisons.

Table (2): Mean \pm SD and $p$-values of ICIQ-SF pre and posttest at both groups.

\begin{tabular}{lccccc}
\hline ICIQ-SF & $\begin{array}{c}\text { Pre test } \\
\text { Mean } \pm \text { SD }\end{array}$ & $\begin{array}{c}\text { Post test } \\
\text { Mean } \pm \text { SD }\end{array}$ & MD & $\begin{array}{c}\% \text { of } \\
\text { change }\end{array}$ & $\begin{array}{c}p- \\
\text { value }\end{array}$ \\
\hline Group A & $13.86 \pm 4.37$ & $6.73 \pm 5.48$ & 7.13 & $51.44 \%$ & $0.0001^{*}$ \\
Group B & $14.13 \pm 4.37$ & $11.26 \pm 5.39$ & 2.87 & $20.3 \%$ & $0.0001^{*}$ \\
MD & -0.27 & -4.53 & & & \\
$p$-value & 0.869 & $0.03^{*}$ & & & \\
$*$ & : Significant level is set at alpha level $<0.05$. & \\
SD : Standard Deviation. & & & \\
MD : Mean Difference. & & \\
$p$-value : Probability value.
\end{tabular}

\section{3- Pelvic floor muscles strength:}

A- Within groups comparisons.

B- Between group comparisons.

Table (3): Mean \pm SD and $p$-values of pelvic floor muscles strength pre and post-test at both groups.

\begin{tabular}{lcllll}
\hline $\begin{array}{l}\text { Pelvic floor } \\
\text { muscles strength }\end{array}$ & $\begin{array}{c}\text { Pre test } \\
\text { Mean } \pm \text { SD }\end{array}$ & $\begin{array}{c}\text { Post test } \\
\text { Mean } \pm \text { SD }\end{array}$ & MD & $\begin{array}{c}\% \text { of } \\
\text { change }\end{array}$ & $\begin{array}{c}p \text { - } \\
\text { value }\end{array}$ \\
\hline Group A & $22.9 \pm 9.54$ & $52.14 \pm 8.91$ & -29.24 & $127 \%$ & $0.0001^{*}$ \\
Group B & $27.1 \pm 9.55$ & $38.41 \pm 10.24$ & -11.31 & $41.7 \%$ & $0.0001^{*}$ \\
MD & -4.2 & 13.73 & & & \\
$p$-value & 0.239 & $0.001^{*}$ & & \\
$*$ & $\quad$ Significant level is set at alpha level <0.05. \\
SD : Standard Deviation. & & & \\
MD : Mean Difference. & & & \\
$p$-value : Probability value. &
\end{tabular}




\section{Discussion}

The main findings of the present study confirmed that the motor imagery training of pelvic floor muscles has effect on urinary incontinence due to over active bladder after incomplete spinal cord injury. The results showed that there was significant statistical difference between mean value of pelvic floor muscles strength and International Consultation on Incontinence Questionnaire Short Form (ICIQ-SF) in both groups (A \& B) in pre and post-treatment, also there was significant statistical difference between mean value of pelvic floor muscles strength and International Consultation on Incontinence Questionnaire Short Form (ICIQ-SF) between both group post-treatment.

This study agreed with Lebon et al., [8] who indicated that muscle strength may benefit from MI training, mainly when movements are under the control of large cortical areas in the primary motor cortex.

In agreement with present study, the result of study of Schuster et al., [9] who mentioned that In several neurological conditions MI has been shown to have beneficial effects as an addition to rehabilitative therapies.

Also, the result of this study agreed with those of Grangeon et al., [10] reported that MI contributed to motor improvements equally as motor execution when integrated into physical therapy in one patient with quadriplegia.

The result of Vijaya et al., [11] matched with present study result. Reported that MIT training also added benefits to improve paretic muscle strength in hip flexors and extensors, knee extensors and dorsiflexors.

This study also agreed with Malouin et al., [12] who also indicated that in numerous clinical studies, the effects of physical therapy or occupational therapy interventions in isolation were compared with the effects of an approach that combined physical and MI practice. These studies consistently found that the greatest improvements in motor performance occurred with interventions that combined physical and mental practice, followed by physical practice alone, and then by MI practice alone, which was superior to no practice at all.

The result of Zijdewind et al., [13] matched with present study result. Also provided evidence that MI may be useful in enhancing the voluntary force of the plantarflexor muscles.
This study disagreed with study of Ietswaart, et al., [14] who determined that caution is warranted since most of the abovementioned findings were based on research on small subgroups of patients, and a recent carefully designed randomised controlled trial did not confirm these initial positive results. As such, there definitely remains a need for additional large-scale randomised controlled trials in this field.

\section{Conclusion:}

We believe that motor imagery training of pelvic floor muscles contraction combined with conventional physical therapy program of pelvic floor exercise and interferential therapy is an effective method to treat urinary incontinence of incomplete spinal cord injury patients with over active bladder.

This study was subjected to several limitations. First the short course of intervention over a period of 4 weeks. Second, sample size was small.

\section{Recommendations:}

1- Future studies can be done with large sample size.

2- The duration of the treatment intervention can be extended.

\section{References}

1- Health Europa. (2019 Jan. 21 st): Could nanotechnology be a form of spinal cord injury treatment?

2- AKKURT H., KARAPOLAT H.U., KIRAZLI Y. and KOSE T.: The effects of upper extremity aerobic exercise in patients with spinal cord injury. Eur. J. Phys. Rehabil. Med., 53: 219-27, 2017.

3- GAJEWSKI J.B. and DRAKE M.J.: Neurological lower urinary tract dysfunction essential terminology. Neurourol. Urodyn., 37 (S6): S25-S31, 2018.

4- GORMLEY E. ANN, DEBORAH J. LIGHTNER, KATHRYN L. BURGIO, TOBY C. CHAI, J. QUENTIN CLEMENS, DANIEL J. CULKIN, ANURAG KUMAR DAS, et al.: Diagnosis and Treatment of Overactive Bladder (Non-Neurogenic) in Adults: AUA/SUFU Guideline. The Journal of Urology, 188: 2455-63, 2012.

5- KHO A.Y., LIU K.P. and CHUNG R.C.: Meta-analysis on the effect of mental imagery on motor recovery of the hemiplegic upper extremity function. Aust. Occup. Ther. J., 61: 38-48, 2014.

6- Di RIENZO F., BLACHE Y., KANTHACK T.F., et al.: Short-term effects of integrated motor imagery practice on muscle activation and force performance. Neuroscience, 305: 146-56, 2015.

7- SHARMA N., POMEROY V.M. and BARON J.C.: Motor imagery: A backdoor to the motor system after stroke? Stroke, 37: 1941-52, 2006. 
8- LEBON F., COLLET C. and GUILLOT A.: Benefits of motor imagery training on muscle strength. J. Strength Cond. Res., 24 (6): 1680-7, 2010.

9- SCHUSTER C., HILFIKER R., AMFT O., SCHEIDHAUER A., ANDREWS B., BUTLER J., et al.: Best practice for motor imagery: A systematic literature review on motor imagery training elements in five different disciplines. BMC Med., 9: 75, 2011.

10- GRANGEON M., GUILLOT A., SANCHO P.O., PICOT M., REVOL P., RODE G., et al.: Rehabilitation of the elbow extension with motor imagery in a patient with quadriplegia after tendon transfer. Arch. Phys. Med. Rehabil., 91: 1143-6, 2010.

11- VIJAYA K. KUMAR, M. CHAKRAPANI and RAKSHITH KEDAMBADI: Motor Imagery Training on Muscle
Strength and Gait Performance in Ambulant Stroke Subjects-A Randomized Clinical Trial. Journal of Clinical and Diagnostic Research, 10 (3): 1-4, 2016.

12- MALOUIN F., BELLEVILLE S., RICHARDS C.L., et al.: Working memory and mental practice outcomes after stroke. Arch. Phys. Med. Rehabil., 85: 177-83, 2004.

13- ZIJDEWIND I., TOERING S.T., BESSEM B., VAN DER LAAN O., and DIERCKS R.L.: Effects of imagery motor training on torque production of ankle plantar flexor muscles. Muscle Nerve, 28: 168-73, 2003.

14- IETSWAART M., JOHNSON M., DIJKERMAN H.C., JOICE S., SCOTT C., MACWALTER S. and HAMILTON S.: Mental practice with motor imagery in stroke recovery: Randomised controlled trial of efficacy. Brain, 134: 137386, 2011.

\section{تآثير التدريب التخيلى الحركى على التبول اللإرادى الجى الحزي

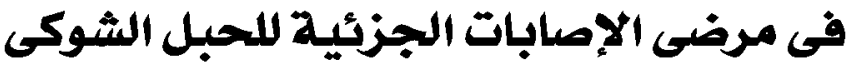

آجريت هذه الدراسة لتحديد تاتثير التدريب التخيلى الصركى لإنقباض عضلات قاع الصوض فى علاج التبول اللاإرادى خاصة فى حالة المثانة النشطة لمرضى الإصابات الجزئية للحبل الثوكئ.

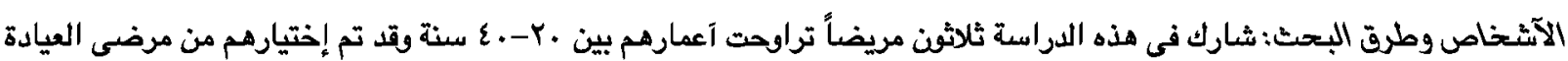

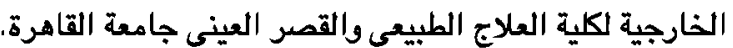
وتم تقسيههم عشو ائياً إلى مجهوعتين:

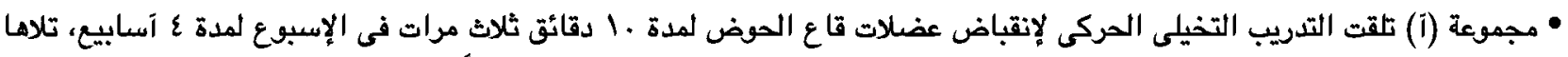

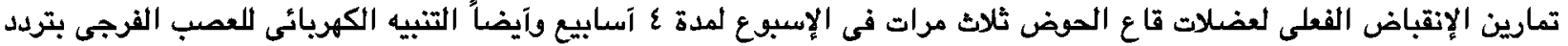

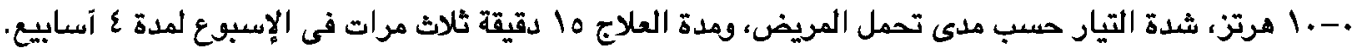
• مجموعة (ب) تلقت تلاها تمارين الإنقباض الفعلى لعضلات قاع الحوض ثلاث مرات فى الإسبوع لمدة ع آسابيع قآيضاً التتبيه الكهريائى للعصب الفرجى بتردد •-_.1 هرتز، شدة التيار حسب مدى تحمل المريض، ومدة العلاج 10 دقيقة ثلاث مرات في الإسبوع لمدة ع آسابيع.

$$
\text { تم القياس بواسطة: }
$$

1- جهاز رد الفعل العضلى · r جع فولت وقد قاس قوة عضلات قاع الحوض قبل ويعد العلاج. ץ- إستيان (المشاوة الدولية حهل نموذج إستبيان سلس البول) وقد قاس آعراض التبول اللاإرادى وتآثيره على جودة الحياة.

النتائج: وقد كثفت النتائج آن تحسن قوة عضلات قاع الحوض له دلالة إحصائية بالنسبة للمجموعة (آ) وكذلك بالنسبة للمجموعة (ب) وقد

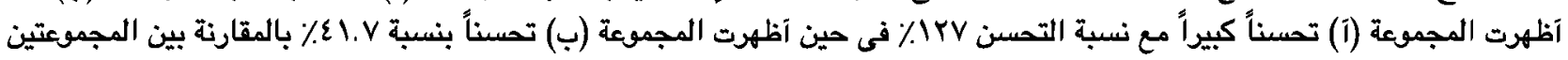

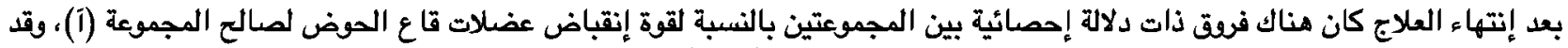

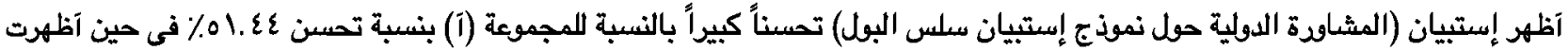

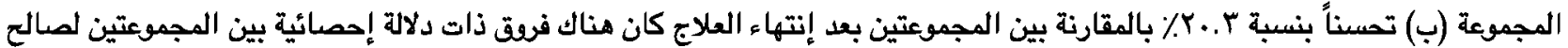

المجموعة (i) (ب)

الإستتاج: آن التخيل الحركى لإنقباض عضلات قاع الحوض آدى إلى تحسن فى قوة عضلات قاع الحوض فآيضاً فى تصسن التبل

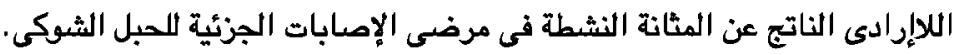

